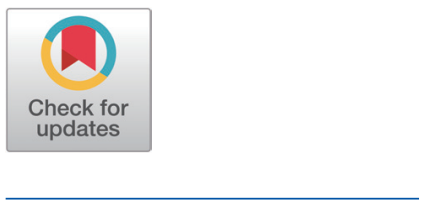

Received: Sep 23, 2020

Revised: Oct 16, 2020

Accepted: Oct 20, 2020

*Corresponding author Jinhyeon Yun

Department of Animal Science, College of Agriculture and Life Sciences,

Chonnam National University, Gwangju 61186 , Korea.

Tel: +82-62-530-2124

E-mail: pilot9939@jnu.ac.kr

Taehee Han

Department of Production Animal Medicine, Faculty of Veterinary

Medicine, University of Helsinki, 04920

Saarentaus, Finland

Tel: +358-50-376-8128

E-mail: taehee.han@helsinki.fi

Copyright $\odot 2021$ Korean Society of

Animal Sciences and Technology.

This is an Open Access article

distributed under the terms of the

Creative Commons Attribution

Non-Commercial License (http://

creativecommons.org/licenses/by-

$\mathrm{nc} / 4.0 /$ ) which permits unrestricted

non-commercial use, distribution, and

reproduction in any medium, provided

the original work is properly cited.

ORCID

Olli Peltoniemi

https://orcid.org/0000-0002-9481-1837

Jinhyeon Yun

https://orcid.org/0000-0002-0697-0679

Stefan Björkman

https://orcid.org/0000-0002-8238-943X

Taehee Han

https://orcid.org/0000-0003-0801-4442

Competing interests

No potential conflict of interest relevant

to this article was reported.

\section{Coping with large litters: the management of neonatal piglets and sow reproduction}

\author{
Olli Peltoniemi ${ }^{1}$, Jinhyeon Yun ${ }^{2 *}$, Stefan Björkman ${ }^{1}$ and Taehee Han ${ }^{1 *}$ \\ ${ }^{1}$ Department of Production Animal Medicine, Faculty of Veterinary Medicine, University of Helsinki, \\ Saarentaus 04920, Finland \\ ${ }^{2}$ Department of Animal Science, College of Agriculture and Life Sciences, Chonnam National University, \\ Gwangju 61186, Korea
}

\begin{abstract}
As a result of intensive breeding, litter size has considerably increased in pig production over the last three decades. This has resulted in an increase in farrowing complications. Prolonged farrowing will shorten the window for suckling colostrum and reduce the chances for high-quality colostrum intake. Studies also agree that increasing litter sizes concomitantly resulted in decreased piglet birth weight and increased within-litter birth weight variations. Birth weight, however, is one of the critical factors affecting the prognosis of colostrum intake, and piglet growth, welfare, and survival. Litters of uneven birth weight distribution will suffer and lead to increased piglet mortality before weaning. The proper management is key to handle the situation. Feeding strategies before farrowing, management routines during parturition (e.g., drying and moving piglets to the udder and cross-fostering) and feeding an energy source to piglets after birth may be beneficial management tools with large litters. Insulin-like growth factor 1 (IGF-1)-driven recovery from energy losses during lactation appears critical for supporting follicle development, the viability of oocytes and embryos, and, eventually, litter uniformity. This paper explores certain management routines for neonatal piglets that can lead to the optimization of their colostrum intake and thereby their survival in large litters. In addition, this paper reviews the evidence concerning nutritional factors, particularly lactation feeding that may reduce the loss of sow body reserves, affecting the growth of the next oocyte generation. In conclusion, decreasing birth weight and compromised immunity are subjects warranting investigation in the search for novel management tools. Furthermore, to increase litter uniformity, more focus should be placed on nutritional factors that affect IGF-1driven follicle development before ovulation.

Keywords: Large litter, Colostrum intake, Lactation feeding, Follicle development, Piglet mortality, Embryonic mortality
\end{abstract}

\section{INTRODUCTION}

During pig breed domestication, breeding has focused on lean tissue deposition, feed conversion efficiency, and above all, on prolificacy (reviewed by [1] and [2]). The larger the litter, the better the profitability for the farmer. Average litter sizes may have increased by $0.2-0.3$ piglets/year [3]. However, 
Funding sources

Not applicable.

Acknowledgements

Not applicable.

Availability of data and material Upon reasonable request, the data sets of this study can be available from the corresponding author.

Authors' contributions

Conceptualization: Peltoniemi O.

Writing - original draft: Peltoniemi O, Yun J, Han T.

Writing - review \& editing: Peltoniemi O, Yun J, Björkman S, Han T.

Ethics approval and consent to participate This article does not require IRB/IACUC approval because there are no human and animal participants. increased litter size is associated with negative aspects such as high energy demand for milk production [4], prolonged farrowing duration [3], and pre-weaning mortality [5].

Based on 20 different studies carried out between 1990 and 2019, litter size has increased from ca. 10 to 20 piglets and farrowing duration has increased from $1.5-2$ to $7-8 \mathrm{~h}$ (Fig. 1) [3,6]. While the described tendency is subject to differences in breeds and farrowing housing environments, the overall tendency is rather convincing. The extended duration of farrowing appears as intensive breeding for prolificacy in the pig [3].

The increasing litter size and prolonged farrowing present as an immunological challenge for the sow and especially the newborn piglets [3,5,7]. With prolonged farrowing , the last $20 \%-30 \%$ of the foetuses to be born seems not to have access to high-quality colostrum, as its quality (i.e., immunoglobulin $\mathrm{G}[\mathrm{IgG}]$ ) rapidly declines after the onset of parturition [8]. They also have less time to suckle on colostrum due to a decreased opportunity for colostrum intake, increased competition for teats, and reduced birth weight [3]. These factors may result in reduced immunity and the emergence of diseases during the growing phase of piglets/fattening pigs.

The metabolic challenge related to the hyper-prolific sow production model begins during gestation and proceeds beyond farrowing and lactation. The sow is supposed to eat enough to meet the nutrient requirements of growing litters prior to farrowing, which may cause some of the problems seen around the time of farrowing [9,10]. During the early stage of lactation, sows with large litters loose more energy while producing more milk that cannot match up with the energy from their feed, ending up in a negative energy balance (NEB) [11,12]. Negative energy balance impacts follicle development after weaning [13-15], oocyte quality [13,14], embryo development $[11,16]$, and piglet birth weight [17]. Thus, pre-mating diets or optimizing the sow metabolic state during lactation may be options for improving subsequent sow fertility.

Growing litter size and production intensity as such appear as items for management issues. This review will explore sow reproduction and piglet survival focusing on large litters and suggest possible management strategies.

\section{PIGLET COLOSTRUM INTAKE AND MORTALITY}

\section{Piglets' first suckling and colostrum intake}

Piglets' first suckling behaviour is the most important factor for colostrum intake, which is crucial

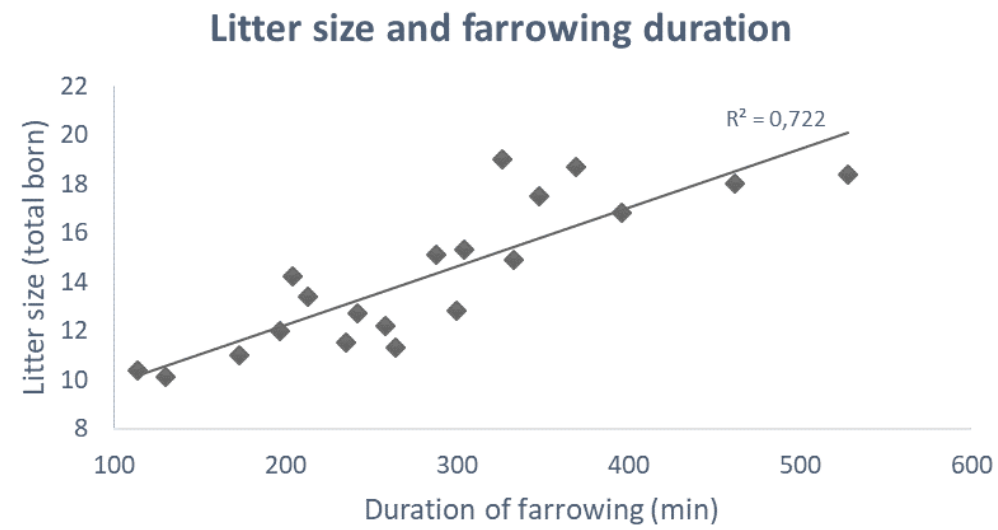

Fig. 1. Increased farrowing duration with increased litter size (a conclusion based on 20 studies on farrowing duration [3]). 
for their survival and growth. Studies have shown that the average time of first suckling ranged from 27 to $62 \mathrm{~min}$ [18-23] and the interval from udder touch to first suckling averaged $9 \min$ [22]. Yun et al. [21] and Balzani et al. [22], showed that the times of the first udder contact (range from 4 to $215 \mathrm{~min}$ ) and colostrum intake (range from 0 to $116 \mathrm{~min}$ ) also varied among individual piglets. The piglets' first suckling behaviour depends on piglet characteristics such as body weight, size and vitality $[19,24]$. If piglets take a longer time until first suckling, they experience more heat and energy loss, lower colostrum intake and a higher mortality rate during lactation [19,21,25]. Thus, the physical characteristics and vitality of piglets can play a crucial role in their survival and growth.

The energy requirement of newborn piglets is very high because of high physical activity and thermoregulation directly after birth [26,27]. Piglets acquire energy mainly from colostrum [8,28], which is mainly composed of moisture, protein, fat and lactose [8,29]. The energy content (e.g., fat and lactose) of colostrum has a major impact on short-term piglet survival during lactation (reviewed by [8]). Colostrum also contains a high concentration of $\operatorname{IgG}[29,30]$, which is essential for piglet immune systems and thereby for their long-term survival during lactation [31]. The composition of colostrum changes nearly hourly. Theil et al. [8] showed that during the first $24 \mathrm{~h}$ after birth, lactose content increased from 3.5\% to 4.4\%, fat content increased from 5.1 to $6.9 \%$, and energy content increased from 260 to $346 \mathrm{~kJ} / 100 \mathrm{~g}$. The concentration of $\mathrm{IgG}$, on the other hand, decreased rapidly by $50 \%$ during the first $6 \mathrm{~h}$ after birth of the first piglet [32] and continued to decrease further during farrowing and until $24 \mathrm{~h}$ after farrowing (e.g., $62.3 \mathrm{vs.} 16.8 \mathrm{mg} / \mathrm{mL}$, respectively for at birth and $24 \mathrm{~h}$ after birth [33]). In modern sows with large litters, changes in energy and $\operatorname{IgG}$ content in colostrum are also similar to those of sows with relatively small litter size despite the increases in litter size and duration of parturition [3,8,34]. In terms of optimizing energy intake, late colostrum (around $12 \mathrm{~h}$ after farrowing) therefore seems more advantageous compared to early colostrum [8]. On the other hand, early colostrum may play a more crucial role in the passive immunity of piglets than late colostrum [32]. Piglet colostrum intake has been shown to positively relate with weaning and inversely related with pre- and post-weaning mortality of the piglets [35]. Declerck et al. [36] and Hasan et al. [37] reported that the colostrum intake of each additional piglet in a large litter decreased by approximately $9 \mathrm{~g}$. This could be due to a limited colostrum yield from the sows [37] and increased competition within litters [38]. Colostrum also contain bioactive factors such as insulin, epidermal growth factor and insulin-like growth factor-1 (IGF-1) [39], which are beneficial for piglet growth and survival. Considering that the energy mobilisations during late gestation are prioritised for mammary growth and colostrum production [8], feeding strategies focusing on late gestation can be one option for improving sow colostrum yield. Also, providing energy source to piglets right after birth has been recommended from many studies (will be discussed below). Therefore, to optimize sow colostrum yield and piglet colostrum intake, nutritional management during late gestation and lactation should be considered more carefully in large litters.

\section{Factors increasing piglet mortality in large litters}

Increased mortality in large litters is of considerable economic and welfare concern in modern pig farming. High pre-weaning mortality in large litters may result from decreased piglet birth weight and increased within-litter birth weight variation (i.e., litter uniformity; Table 1) [5,40,41]. Correspondingly, the number of piglets weaned has not perfectly matched with increased litter size. Recent studies showed that total pre-weaning mortality, including stillbirths, ranged from $13 \%$ to $15 \%$ in large litters [42-44]. In severe case, sows kept under risky conditions with a large litter of an average 19 piglets have $17.9 \%$ of piglet mortality during the first day of lactation in open farrowing crate [21]. Among pre-weaning mortality, $72 \mathrm{~h}$ of postnatal life is the most critical 
Table 1. Regression coefficients $(\beta)$ between the number of total piglets born and litter characteristics at birth in sows

\begin{tabular}{|c|c|c|c|c|}
\hline & \multicolumn{4}{|c|}{ Total number of piglets born $(n)$} \\
\hline & Milligan et al. [40] $]^{1)}$ & Wienjtes et al. [5] $]^{2)}$ & Wientjes et al. $[17]^{3)}$ & Han et al. $[41]^{4)}$ \\
\hline \multicolumn{5}{|l|}{ Litter characteristics } \\
\hline Mean birth weight $(\mathrm{g})$ & $-46^{* * *}$ & $-40^{* * *}$ & $-41^{* * *}$ & $-37^{* * *}$ \\
\hline CV of birth weight (\%) & $0.39^{* * *}$ & $0.76^{* * *}$ & $0.83^{* * *}$ & $0.60^{* *}$ \\
\hline Piglets < 1,000 g (\%) & - & $2.4^{* * *}$ & $1.9^{* * *}$ & $2.0^{* * *}$ \\
\hline \multicolumn{5}{|c|}{${ }^{1)}$ Conventional YL sows, 10.7 total born piglets $(n=4,222)$} \\
\hline \multicolumn{5}{|c|}{ 2) Organic Topigs20 sows, 17.4 total born piglets $(n=1,864)$. } \\
\hline \multicolumn{5}{|c|}{${ }^{3)}$ Conventional Topigs 20 and Topigs 40 sows, 13.5 total born piglets $(n=2,128)$. } \\
\hline \multicolumn{5}{|c|}{${ }^{4)}$ Conventional DanAvl sows, 19.1 total born piglets $(n=1,065)$. } \\
\hline \multicolumn{5}{|l|}{${ }^{* *} p<0.01,{ }^{* * *} p<0.001$} \\
\hline CV, coefficient of variation; & L, Yorkshire Landrace. & & & \\
\hline
\end{tabular}

period (for review, see [45]). The great majority of piglet mortality is caused by crushing, starvation and hypothermia [46]. In particular, starvation and hypothermia, which can be derived mainly from piglet characteristics, may cause piglet crushing and death during lactation [47]. Low birth weight in piglets may be linked to lower vitality/viability [48], a longer time to the first suckle [25], and less ability to compete for colostrum intake with littermates (for a review, see [35]). Moreover, limited capacity to ingest colostrum of low-birth-weight piglets [49] could be one of the reasons for impaired colostrum intake [50]. Furthermore, Baxter et al. [19] have demonstrated that piglets that die before weaning had lower birth weights and lower rectal temperatures at birth and $1 \mathrm{~h}$ after birth compared to piglets that survived. This may imply that hypothermia can also be an important mortality factor in low-birth-weight piglets. Indeed, Herpin et al. [27] showed that smaller piglets may experience greater heat loss and thus a decreased ability to thermoregulate when compared to larger piglets. Considering that low-birth-weight piglets showed higher mortality, especially during the first $24 \mathrm{~h}$ after birth [51,52], certain supportive management routines around parturition will be needed in the management of large litters will be discussed.

Litter uniformity, in addition to individual birth weight, can be a major factor affecting piglet mortality. Increased litter size resulted in poor litter uniformity, which elicited a higher proportion of small piglets (< 1,000 g; Table 1) [5,17,41]. Results by Wientjes et al. [5] support this finding, as they showed the coefficient of variation $(\mathrm{CV})$ of birth weight to positively relate to mortality during the first three days after birth in large litters. Furthermore, poor litter uniformity (i.e., large variation of within-litter birth weights) resulted in less colostrum yield by sows [50] and unevenly distributed colostrum intake by piglets (reviewed by [36]). Poor uniformity at birth causes not only high mortality but also poor uniformity at weaning [40,52]. Thus, improving litter uniformity, either by pre-mating nutritional strategies or breeding, is of great interest with regard to large litters.

Stillborn piglets are also of great concern in large litters. Generally, stillborn rates in piglets have been in the range of 5\%-10\% in recent studies (reviewed by [53]). Stillborns can be classified into two types, depending on their time of death [54]. Piglets in one group die before parturition (antepartum or prepartum death; type 1), while piglets in the second group die during parturition, which represents a great majority of all cases (intra-partum death; type 2; [55]). Increased farrowing duration with higher litter size (Fig. 1) may increase type 2 stillborn rates. Canario et al. [56] reported a potentially higher risk of stillborn piglets with a litter size of more than 14 piglets. A recent study also found that a higher stillborn rate was related to larger litter size [57], which is in accordance with earlier studies [58,59]. This may be explained by the greater risk of asphyxiation after detachment of the placenta [60], possibly due to increased farrowing duration. 


\section{Feeding strategies for improving piglet survival}

Based on the findings of high mortality in large litters, management strategies for increasing piglet survival rate should focus on strategies applicable during late gestation and before parturition and strategies applicable after birth. In the review of Theil et al. [8], they addressed the importance of sow nutrition in late gestation on colostrum yield and composition. Briefly, different dietary composition during late lactation may alter both colostrum yield and quality. Before parturition, high-fibre diets seems to result in an improved farrowing process $[10,61]$ and colostrum production [8], and thereafter in reduced pre-weaning mortality [61]. Frequent daily meals (more than thrice daily) before farrowing are recommended for improving both the energy status and farrowing process of sows with large litters [62]. For example, Feyera et al. [62] observed that sows with a shorter time from the last meal until the onset of farrowing had a shorter farrowing duration, less probability of requiring farrowing assistance, and a low number of stillbirths. This finding may suggest that decreasing serum glucose levels may be one of the mechanisms through which farrowing duration is prolonged.

Dewey et al. [63] found that farms that provided oral administration of colostrum or glucose to piglets and performed split-nursing showed higher survival rates compared to farms with less intensive management. Especially for weak piglets, helping to establish breathing, assisting them in reaching the udder, and keeping them warm may also be recommended, as suggested by Herpin et al. [60]. These management routines can reduce the time of first suckling [20,60,64], thereby leading to an increase in colostrum intake and survival rate. Vasdal et al. [20] stressed that drying piglets and placing them onto the udder of the sow directly after birth is a key point for optimizing neonatal survival in large litters. They found less than $10 \%$ mortality (of total born) in a litter with over 15 total piglets in the open-farrowing system with intensive piglet management routines. This mortality rate is indeed low when compared with a mortality rate of $17.9 \%$ observed during the first $24 \mathrm{~h}$ after birth in litters of hyper-prolific sows that had not been given management routines at birth [21].

Providing energy supplementation to small piglets by hand has also been recently studied as a means to cope with the insufficient energy intake of piglets in large litters [42,65-68]. Declerck et al. [65] showed that pre-weaning mortality was reduced when small piglets were fed with energy supplementation (e.g., soy oil and coconut oil) directly after birth. Glycerol-rich supplementation and colostrum replacers also seemed to be beneficial for small piglet survival [68]. On the other hand, some studies did not find an increased survival rate with energy supplementation (sow colostrum and coconut oil) [42,67]. Thus, both drying piglets and providing them with energy supplementation, and thereafter moving them to the sow's udder may be the most effective management routines for optimizing piglet survival in large litters.

\section{SOW LACTATIONAL BODY CONDITION LOSS AND SUB- SEQUENT FERTILITY}

\section{Lactational body condition loss and follicle development}

Sows lose their body condition mostly during lactation. The losses consist of both protein and lipid. In practical situations, backfat thickness is widely measured to predict sow lipid status. Loin muscle depth, which represents protein status, contains relevant information on sow metabolic state and reproductive performance, especially if lean sow lines are used for breeding [11,14,15]. The increased number of suckling piglets in large litters resulted in sows being in severe NEB (attributed to the loss of proteins, lipids, or both) during lactation [4]. This is caused by the high metabolic demands 
for milk production [69]. Severe NEB (e.g., approximately 10\%-12\% body weight loss) may compromise subsequent fertility, causing e.g., extended weaning-to-oestrus intervals (WEI), lower pregnancy rates, and lower subsequent litter size [70]. In modern hyper-prolific sows, however, severe NEB appears to associate with a lower ovulation rate $(\mathrm{OR})$ or embryo survival rather than extended WEI (reviewed by [71]).

Impaired OR or embryo survival can be explained by compromised follicle development at weaning. Severe NEB resulted in smaller follicle diameter at weaning [13-15,72]. This may originate from the detrimental effect of NEB on luteinizing hormone (LH) and follicle development. In early lactation, $\mathrm{LH}$ is suppressed by sucking-induced inhibition of the $\mathrm{GnRH}$ (reviewed by [73]). As lactation progressed, LH pulsatility is normally restored [74], which stimulates follicle development. However, sows with low feed intake had lower LH pulsatility and smaller follicles at weaning compared to sows with high feed intake during lactation.

In large litters, follicle diameter at weaning is approximately $4-5 \mathrm{~mm}[14,15]$. After weaning, pulsatile $\mathrm{GnRH}$ release may induce the release of both $\mathrm{LH}$ and follicle-stimulating hormone (FSH), which are important for follicle growth and ovulation [75]. As a result, follicles grow to reach the pre-ovulatory size $(7-8 \mathrm{~mm})[15,76,77]$ usually within seven days after weaning (reviewed by [71]). Smaller follicle diameter at weaning is related to longer WEI and weaningto-ovulation interval (WOI) $[15,78-80]$. This is because smaller follicles take more time to reach the pre-ovulatory phase [79], after which oestrogens produced by pre-ovulatory follicles result in oestrus and ovulation (reviewed by [78]).

Further, sow metabolic state may represent the follicular fluid metabolic state, as follicular fluid can be considered an exudate of sow blood. In the study by Costermans et al. [14], plasma IGF-1 level, which is negatively related to sow body condition loss during lactation [14,15], was strongly related to follicular fluid IGF-1 level after weaning. As follicular IGF-1 is important for follicle and oocyte development $[14,15]$, the importance of sow metabolic state on follicle and oocyte development seems to be clear.

\section{Follicle development and subsequent fertility}

A schematic drawing of the relationship between sow NEB during lactation and litter uniformity at subsequent parturition is described in Fig. 2. [5]. This may be explained by the detrimental effect of sow body condition loss on follicle development and subsequent fertility. Follicle development before ovulation plays a major role in oocyte quality, embryo development and, eventually, piglet characteristics at birth in sows (reviewed by [81]).

Studies have shown that impaired follicle development at weaning can result in a compromised follicle pool before ovulation [72] and a lower oocyte maturation rate [13,14]. Further, there is a positive relationship between follicle diameter at ovulation and corpus luteum (CL) diameter after ovulation [76,82]. Good CL development is necessary for embryo development during early pregnancy $[2,83,84]$, as CL has been shown to positively relate with progesterone level and pulse [85-88]. Smaller follicles at ovulation may therefore be detrimental for early embryo development. Considering that piglet characteristics are largely determined at the early embryo developmental stage [89], we suggest that follicle diameters at weaning may also be related to piglet characteristics. Likewise, the heterogeneity of the follicle pool before ovulation may have an impact on litter uniformity at birth with a similar mechanism (reviewed by [71]).

IGF-1 is a possible mediator affecting follicle and oocyte development. It is very important in follicular fluid, as it can bind to IGF-1 receptors on the oocytes and granulosa cells. Once bound, it may synergize with FSH so as to activate follicular growth, steroidogenesis, and the oocyte cleavage rate [90-93]. A recent study also found that IGF-1 in the follicular fluid is positively related to 


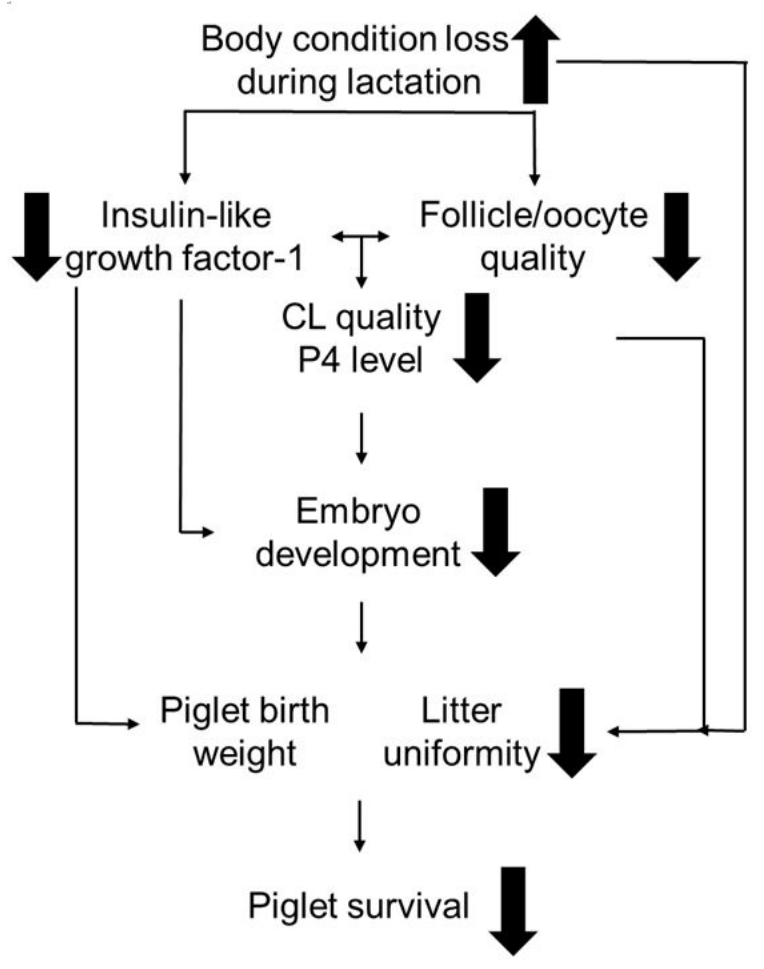

Fig. 2. Schematic illustration of body condition loss during lactation and the IGF-1 level, follicle/oocyte quality, embryo survival, and litter characteristics and its consequences for piglet survival. $\mathrm{CL}$, corpus luteum; IGF, Insulin-like growth factor.

follicle diameter before ovulation [14]. During WEI, sow plasma IGF-1 level is strongly related to the follicular IGF-1 level [14] and its levels at weaning are positively related to those during WEI $[15,94]$. Thus, higher IGF-1 and larger follicles at weaning appear to favour higher oocyte quality. The IGF-1 level around ovulation is also positively related to CL diameter and the increment of progesterone level after ovulation [95], and to embryo survival during early pregnancy [11]. Our recent study observed that higher plasma IGF-1 before ovulation (at oestrus) was positively related to piglet mean birth weight [41]. Thus, IGF-1 -mediating follicle development, which was affected by NEB $[14,15]$, has a major impact on subsequent sow fertility. In addition, extracellular vesicles may be among further mechanisms through which NEB-driven reduction in follicle development can affect the developing ova within the follicle, as shown for canines in vitro [96].

\section{Embryonic mortality in large litters}

As a consequence of breeding for a large litter, the ovulation rate (OR) has increased and is currently approximate to 25-30 (reviewed by [97]). Embryonic and piglet mortality have increased with increased OR $[97,98]$. However, the number of piglets could only increase to a certain limit because of the higher embryonic mortality associated with increased OR (reviewed by [97]). Early embryonic mortality occurs before implantation (around 12 or 13 days of gestation), while late embryonic mortality occurs after implantation between 13 and 35 days of gestation. In sows, early embryonic mortality increased with increasing OR and was approximately 59\% of the total embryonic mortality [97]. Embryonic heterogeneity within litters may be a major reason for early embryonic mortality. Less-developed embryos cannot develop further in a uterine environment, which is advanced by the more-developed embryos (reviewed by [99]). In detail, 
oestradiol produced from more-developed embryos stimulates uterine secretions for their own implantation but this results in an unfavourable environment for less-developed embryos [100,101]. Synchrony between developing embryos and the uterine environment is important for successful implantation. Embryos lagging behind in development may experience a uterine environment that is asynchronous with their own development and implantation may therefore fail [102]. Considering that embryonic heterogeneity is largely affected by follicle heterogeneity $[99,103]$, the importance of follicle development before ovulation is once again highlighted. However, increased OR also seems to associate with compromised follicle development. Sows with increased OR showed decreased CL diameters, which were derived from a decreased follicle diameter [76,82]. This implies that breeding for a large litter likely contributed to compromised follicle development. Although less-developed embryos may survive through the implantation process, they may be more vulnerable to dying later during gestation. Late embryonic mortality was ca. $42 \%$ of the total mortality and it also increased as OR increased [97]. Limited uterine capacity and competition for space and/or nutrients are major reasons for late embryonic mortality (reviewed by [101]). Da Silva et al. [97] showed that embryos with small size and small implantation sites had higher mortality at a late stage of pregnancy. The small size of the implantation site can be linked to a small placental site [104], which may be harmful to foetal development.

\section{Management routines during/after lactation for subsequent fertility}

Only five or six days of WEI appears too short to recover from severe NEB in hyper-prolific sows and to support their follicles in reaching the pre-ovulatory size and high-quality oocytes. Thus, skipping the first heat and inseminating at the second oestrus may be recommended for sows with severe body condition loss during lactation. This recommendation stems from the study showing that a longer weaning-to-pregnancy interval (WPI; > 21 day) resulted in better litter uniformity (i.e., lower SD and CV at birth weight; [17]. Wientjes et al. [17] explained that this may be due to the longer recovery of metabolic states and the restoration of follicle development, which is beneficial for subsequent fertility.

Pre-mating diets are one option for stimulating follicle and oocyte development. A fibre-rich pre-mating diet (e.g., sugar beet pulp) before ovulation can have a positive impact on oocyte quality and maturation in the gilts [105]. Furthermore, supplementing insulin- or IGF-1-stimulating diets (dextrose and lactose) during lactation and WEI can improve litter uniformity $[106,107]$. Nevertheless, only a few nutritional factors have been evaluated as components of pre-mating diets. Considering that sow IGF-1 levels after weaning are positively related to pre-weaning levels $[15,94]$, pre-mating diets during the late or whole lactation period may prove effective. Optimizing sow metabolic state during lactation is also recommended. This may be done by identifying the ideal feed composition of lactation diets, such as protein and amino acids levels, especially in a hyper-prolific situation.

\section{CONCLUSION}

Large litters do not come without a catch. Increased litter size creates problems with piglet survival during lactation and sow reproduction that need addressing. Large litters only occur through increased ORs. These rates are associated with compromised follicles that appear to negatively affect early embryonic development and pregnancy-supporting mechanisms such as CL development. These impaired developments result in increased embryonic and foetal mortality. At the end of pregnancy, the process of parturition also seems tightly linked with litter size. Increased litter size prolongs the process of parturition, leaving a proportion of the litter with reduced chances 
for suckling high-quality colostrum for a reduced period of time under increased competition Therefore, farrowing, early lactation management procedures and late lactation nutritional management are keys to tackling the increasing problems associated with large litters. In particular, feeding strategies before farrowing can be recommended for reducing farrowing duration. For neonatal piglets, additional management routines during parturition may increase piglet colostrum intake and their survival. Nutritional management of the sow around the end of lactation, involving IGF-1-driven follicle development, seems to be important for piglet birth weight and survival at subsequent farrowing.

\section{REFERENCES}

1. Clutter AC. Genetic selection for lifetime reproductive performnace. In: Rodriguez-Martinez H, Vallet JL, Ziecik AJ, editors. Control of pig reproduction VIII. Nottingham: Nottingham University Press; 2009. p. 293-302.

2. Foxcroft GR. Mechanisms mediating nutritional effects on embryonic survival in pigs. J Reprod Fertil Suppl. 1997;52:47-61.

3. Oliviero C, Junnikkala S, Peltoniemi O. The challenge of large litters on the immune system of the sow and the piglets. Reprod Domest Anim. 2019;54:12-21. https://doi.org/10.1111/ rda. 13463

4. Strathe AV, Bruun TS, Hansen CF. Sows with high milk production had both a high feed intake and high body mobilization. Animal. 2017;11:1913-21. https://doi.org/10.1017/ S1751731117000155

5. Wientjes JGM, Soede NM, van der Peet-Schwering CMC, van den Brand H, Kemp B. Piglet uniformity and mortality in large organic litters: effects of parity and pre-mating diet composition. Livest Sci. 2012;144:218-29. https://doi.org/10.1016/j.livsci.2011.11.018

6. Jackson JR, Hurley WL, Easter RA, Jensen AH, Odle J. Effects of induced or delayed parturition and supplemental dietary fat on colostrum and milk composition in sows. J Anim Sci. 1995;73:1906-13. https://doi.org/10.2527/1995.7371906x

7. Oliviero C. Management to improve neonate piglet survival. In: Rodriqez-Martinez H, Soede NM, Flowers WL, editors. Control of pig reproduction IX. Leicestershire: Context Products; 2013. p. 203-10.

8. Theil PK, Lauridsen C, Quesnel H. Neonatal piglet survival: impact of sow nutrition around parturition on fetal glycogen deposition and production and composition of colostrum and transient milk. Animal. 2014;8:1021-30. https://doi.org/10.1017/S1751731114000950

9. Oliviero C, Heinonen M, Valros A, Hälli O, Peltoniemi OAT. Effect of the environment on the physiology of the sow during late pregnancy, farrowing and early lactation. Anim Reprod Sci. 2008;105:365-77. https://doi.org/10.1016/j.anireprosci.2007.03.015

10. Oliviero C, Kokkonen T, Heinonen M, Sankari S, Peltoniemi O. Feeding sows with high fibre diet around farrowing and early lactation: impact on intestinal activity, energy balance related parameters and litter performance. Res Vet Sci. 2009;86:314-9. https://doi.org/10.1016/ j.rvsc.2008.07.007

11. Hoving L, Soede N, Feitsma H, Kemp B. Lactation weight loss in primiparous sows: consequences for embryo survival and progesterone and relations with metabolic profiles. Reprod Domest Anim. 2012;47:1009-16. https://doi.org/10.1111/j.1439-0531.2012.02007.x

12. Costermans NGJ, Teerds KJ, Keijer J, Knol EF, Koopmanschap RE, Kemp B, et al. Follicular development of sows at weaning in relation to estimated breeding value for within-litter variation in piglet birth weight. Animal. 2019;13:554-63. https://doi.org/10.1017/ 


\section{S1751731118001684}

13. Zak LJ, Xu X, Hardin RT, Foxcroft GR. Impact of different patterns of feed intake during lactation in the primiparous sow on follicular development and oocyte maturation. J Reprod Fertil. 1997;110:99-106. https://doi.org/10.1530/jrf.0.1100099

14. Costermans NGJ, Teerds KJ, Middelkoop A, Roelen BAJ, Schoevers EJ, van Tol HTA, et al. Consequences of negative energy balance on follicular development and oocyte quality in primiparous sows. Biol Reprod. 2020;102:388-98. https://doi.org/10.1093/BIOLRE/IOZ175

15. Han T, Björkman S, Soede NM, Oliviero C, Peltoniemi OAT. IGF-1 concentration patterns and their relationship with follicle development after weaning in young sows fed different pre-mating diets. Animal. 2020;14:1493-501. https://doi.org/10.1017/S1751731120000063

16. Patterson JL, Smit MN, Novak S, Wellen AP, Foxcroft GR. Restricted feed intake in lactating primiparous sows. I. Effects on sow metabolic state and subsequent reproductive performance. Reprod Fertil Dev. 2011;23:889-98. https://doi.org/10.1071/RD11015

17. Wientjes JGM, Soede NM, Knol EF, van den Brand H, Kemp B. Piglet birth weight and litter uniformity: effects of weaning-to-pregnancy interval and body condition changes in sows of different parities and crossbred lines. J Anim Sci. 2013;91:2099-107. https://doi. org/10.2527/jas.2012-5659

18. Tuchscherer M, Puppe B, Tuchscherer A, Tiemann U. Early identification of neonates at risk: traits of newborn piglets with respect to survival. Theriogenology. 2000;54:371-88. https://doi. org/10.1016/S0093-691X(00)00355-1

19. Baxter EM, Jarvis S, D'Eath RB, Ross DW, Robson SK, Farish M, et al. Investigating the behavioural and physiological indicators of neonatal survival in pigs. Theriogenology. 2008;69:773-83. https://doi.org/10.1016/j.theriogenology.2007.12.007

20. Vasdal G, Østensen I, Melišová M, Bozděchová B, Illmann G, Andersen IL. Management routines at the time of farrowing-effects on teat success and postnatal piglet mortality from loose housed sows. Livest Sci. 2011;136:225-31. https://doi.org/10.1016/j.livsci.2010.09.012

21. Yun J, Han T, Björkman S, Nystén M, Hasan S, Valros A, et al. Factors affecting piglet mortality during the first $24 \mathrm{~h}$ after the onset of parturition in large litters: effects of farrowing housing on behaviour of postpartum sows. Animal. 2019;13:1045-53. https://doi.org/10.1017/ S1751731118002549

22. Balzani A, Cordell HJ, Edwards SA. Relationship of sow udder morphology with piglet suckling behavior and teat access. Theriogenology. 2016;86:1913-20. https://doi.org/10.1016/ j.theriogenology.2016.06.007

23. Christison GI, Wenger II, Follensbee ME. Teat seeking success of newborn piglets after drying or warming. Can J Anim Sci. 1997;77:317-9. https://doi.org/10.4141/A96-119

24. Baxter EM, Jarvis S, Sherwood L, Robson SK, Ormandy E, Farish M, et al. Indicators of piglet survival in an outdoor farrowing system. Livest Sci. 2009;124:266-76. https://doi. org/10.1016/j.livsci.2009.02.008

25. Pedersen LJ, Berg P, Jørgensen G, Andersen IL. Neonatal piglet traits of importance for survival in crates and indoor pens. J Anim Sci. 2011;89:1207-18. https://doi.org/10.2527/ jas.2010-3248

26. Le Dividich J, Rooke JA, Herpin P. Nutritional and immunological importance of colostrum for the new-born pig. J Agric Sci. 2005;143:469-85. https://doi.org/10.1017/ S0021859605005642

27. Herpin P, Damon M, Le Dividich J. Development of thermoregulation and neonatal survival in pigs. Livest Prod Sci. 2002;78:25-45. https://doi.org/10.1016/S0301-6226(02)00183-5

28. Le Dividich J, Esnault T, Lynch B, Hoo-Paris R, Castex C, Peiniau J. Effect of colostral fat 
level on fat deposition and plasma metabolites in the newborn pig. J Anim Sci. 1991;69:24808. https://doi.org/10.2527/1991.6962480x

29. Yun J, Swan KM, Vienola K, Kim YY, Oliviero C, Peltoniemi OAT, et al. Farrowing environment has an impact on sow metabolic status and piglet colostrum intake in early lactation. Livest Sci. 2014;163:120-5. https://doi.org/10.1016/j.livsci.2014.02.014

30. Hasan SMK, Junnikkala S, Peltoniemi O, Oliviero C. Validation of Brix refractometer to estimate colostrum immunoglobulin $\mathrm{G}$ content and composition in the sow. Animal. 2016;10:1728-33. https://doi.org/10.1017/S1751731116000896

31. Devillers N, Le Dividich J, Prunier A. Influence of colostrum intake on piglet survival and immunity. Animal. 2011;5:1605-12. https://doi.org/10.1017/S175173111100067X

32. Devillers N, Farmer C, Mounier AM, LeDividich J, Prunier A. Hormones, IgG and lactose changes around parturition in plasma, and colostrum or saliva of multiparous sows. Reprod Nutr Dev. 2004;44:381-96. https://doi.org/10.1051/rnd:2004043

33. Quesnel H. Colostrum production by sows: variability of colostrum yield and immunoglobulin G concentrations. Animal. 2011;5:1546-53. https://doi.org/10.1017/S175173111100070X

34. Klobasa F, Werhahn E, Butler JE. Composition of sow milk during lactation. J Anim Sci. 1987;64:1458-66. https://doi.org/10.2527/jas1987.6451458x

35. Declerck I, Dewulf J, Sarrazin S, Maes D. Long-term effects of colostrum intake in piglet mortality and performance. J Anim Sci. 2016;94:1633-43. https://doi.org/10.2527/jas.20159564

36. Declerck I, Sarrazin S, Dewulf J, Maes D. Sow and piglet factors determining variation of colostrum intake between and within litters. Animal. 2017;11:1336-43. https://doi.org/10.1017/ S1751731117000131

37. Hasan S, Orro T, Valros A, Junnikkala S, Peltoniemi O, Oliviero C. Factors affecting sow colostrum yield and composition, and their impact on piglet growth and health. Livest Sci. 2019;227:60-7.https://doi.org/10.1016/j.livsci.2019.07.004

38. Milligan BN, Fraser D, Kramer DL. The effect of littermate weight on survival, weight gain, and suckling behavior of low-birth-weight piglets in cross-fostered litters. J Swine Health Prod. 2001;9:161-8.

39. Xu RJ, Sangild PT, Zhang YQ, Zhang SH. Chapter 5 Bioactive compounds in porcine colostrum and milk and their effects on intestinal development in neonatal pigs. Biol Grow Anim. 2002;1:169-92. https://doi.org/10.1016/S1877-1823(09)70121-3

40. Milligan BN, Fraser D, Kramer DL. Within-litter birth weight variation in the domestic pig and its relation to pre-weaning survival, weight gain, and variation in weaning weights. Livest Prod Sci. 2002;76:181-91. https://doi.org/10.1016/S0301-6226(02)00012-X

41. Han T, Björkman S, Soede N, Oliviero C, Peltoniemi OAT. IGF-1 concentrations after weaning in young sows fed different pre-mating diets are positively associated with piglet mean birth weight at subsequent farrowing. Animal. Forthcoming 2020.

42. Schmitt O, O’Driscoll K, Boyle LA, Baxter EM. Artificial rearing affects piglets pre-weaning behaviour, welfare and growth performance. Appl Anim Behav Sci. 2019;210:16-25. https:// doi.org/10.1016/j.applanim.2018.10.018

43. Kobek-Kjeldager C, Moustsen VA, Theil PK, Pedersen LJ. Effect of litter size, milk replacer and housing on production results of hyper-prolific sows. Animal. 2020;14:824-33. https:// doi.org/10.1017/S175173111900260X

44. van den Bosch M, Wijnen J, van de Linde IB, van Wesel AAM, Melchior D, Kemp B, et al. Effects of maternal dietary nitrate supplementation on farrowing and placental characteristics, level of asphyxiation at birth and piglet vitality. Theriogenology. 2019;129:1-7. https://doi. 
org/10.1016/j.theriogenology.2019.01.033

45. Edwards SA, Baxter EM. Piglet mortality: causes and prevention. In: Farmer C, editor. Gestating and lactating sow. Wageningen: Wageningen Academic Publishers; 2015.p. 253-78.

46. Edwards SA. Perinatal mortality in the pig: environmental or physiological solutions? Livest Prod Sci. 2002;78:3-12. https://doi.org/10.1016/S0301-6226(02)00180-X

47. Weary DM, Pajor EA, Fraser D, Honkanen AM. Sow body movements that crush piglets: a comparison between two types of farrowing accommodation. Appl Anim Behav Sci. 1996;49:149-58. https://doi.org/10.1016/0168-1591(96)01042-8

48. Muns R, Manzanilla EG, Sol C, Manteca X, Gasa J. Piglet behavior as a measure of vitality and its influence on piglet survival and growth during lactation.J Anim Sci. 2013;91:1838-43. https://doi.org/10.2527/jas.2012-5501

49. Amdi C, Krogh U, Flummer C, Oksbjerg N, Hansen CF, Theil PK. Intrauterine growth restricted piglets defined by their head shape ingest insufficient amounts of colostrum. J Anim Sci. 2013;91:5605-13. https://doi.org/10.2527/jas.2013-6824

50. Quesnel H, Farmer C, Devillers N. Colostrum intake: influence on piglet performance and factors of variation. Livest Sci. 2012;146:105-14. https://doi.org/10.1016/j.livsci.2012.03.010

51. Quesnel H, Brossard L, Valancogne A, Quiniou N. Influence of some sow characteristics on within-litter variation of piglet birth weight. Animal. 2008;2:1842-9. https://doi.org/10.1017/ S175173110800308X

52. Quiniou N, Dagorn J, Gaudré D. Variation of piglets' birth weight and consequences on subsequent performance. Livest Prod Sci. 2002;78:63-70. https://doi.org/10.1016/S03016226(02)00181-1

53. Langendijk P, Plush K. Parturition and s relationship with stillbirths and asphyxiated piglets. Animals. 2019;9:885. https://doi.org/10.3390/ani9110885

54. Sprecher DJ, Leman AD, Dziuk PD, Cropper M, DeDecker M. Causes and control of swine stillbirths.J Am Vet Med Assoc. 1974;165:698-701.

55. Rangstrup-Christensen L, Schild SLA, Pedersen LJ, Sørensen JT. Causes of preweaning mortality in organic outdoor sow herds. Res Vet Sci. 2018;118:171-80. https://doi.org/10.1016/ j.rvsc.2018.02.010

56. Canario L, Cantoni E, Le Bihan E, Caritez JC, Billon Y, Bidanel JP, et al. Between-breed variability of stillbirth and its relationship with sow and piglet characteristics. J Anim Sci. 2006;84:3185-96. https://doi.org/10.2527/jas.2005-775

57. Björkman S, Oliviero C, Rajala-Schultz PJ, Soede NM, Peltoniemi OAT. The effect of litter size, parity and farrowing duration on placenta expulsion and retention in sows. Theriogenology. 2017;92:36-44. https://doi.org/10.1016/j.theriogenology.2017.01.003

58. van Dijk AJ, van Rens BTTM, van der Lende T, Taverne MAM. Factors affecting duration of the expulsive stage of parturition and piglet birth intervals in sows with uncomplicated, spontaneous farrowings. Theriogenology. 2005;64:1573-90. https://doi.org/10.1016/j.theriogenology.2005.03.017

59. Oliviero C, Heinonen M, Valros A, Peltoniemi O. Environmental and sow-related factors affecting the duration of farrowing. Anim Reprod Sci. 2010;119:85-91. https://doi.org/10.1016/ j.anireprosci.2009.12.009

60. Herpin P, Le Dividich J, Hulin JC, Fillaut M, De Marco F, Bertin R. Effects of the level of asphyxia during delivery on viability at birth and early postnatal vitality of newborn pigs. J Anim Sci. 1996;74:2067-75. https://doi.org/10.2527/1996.7492067x

61. Feyera T, Højgaard CK, Vinther J, Bruun TS, Theil PK. Dietary supplement rich in fiber fed to late gestating sows during transition reduces rate of stillborn piglets1. J Anim Sci. 
2017;95:5430-8. https://doi.org/10.2527/jas2017.2110

62. Feyera T, Pedersen TF, Krogh U, Foldager L, Theil PK. Impact of sow energy status during farrowing on farrowing kinetics, frequency of stillborn piglets, and farrowing assistance. J Anim Sci. 2018;96:2320-31. https://doi.org/10.1093/jas/sky141

63. Dewey CE, Gomes T, Richardson K. Field trial to determine the impact of providing additional care to litters on weaning weight of pigs. Can J Vet Res. 2008;72:390-5.

64. Andersen IL, Haukvik IA, Bøe KE. Drying and warming immediately after birth may reduce piglet mortality in loose-housed sows. Animal. 2009;3:592-7. https://doi.org/10.1017/ S1751731108003650

65. Declerck I, Dewulf J, Decaluwé R, Maes D. Effects of energy supplementation to neonatal (very) low birth weight piglets on mortality, weaning weight, daily weight gain and colostrum intake. Livest Sci. 2016;183:48-53. https://doi.org/ 10.1016/j.livsci.2015.11.015

66. Moreira LP, Menegat MB, Barros GP, Bernardi ML, Wentz I, Bortolozzo FP. Effects of colostrum, and protein and energy supplementation on survival and performance of low-birthweight piglets. Livest Sci. 2017;202:188-93. https://doi.org/ 10.1016/j.livsci.2017.06.006

67. Muns R, Silva C, Manteca X, Gasa J. Effect of cross-fostering and oral supplementation with colostrums on performance of newborn piglets. J Anim Sci. 2014;92:1193-9. https://doi.org/ 10.2527/jas.2013-6858

68. Muns R, Nuntapaitoon M, Tummaruk P. Effect of oral supplementation with different energy boosters in newborn piglets on pre-weaning mortality, growth and serological levels of IGF-I and IgG. J Anim Sci. 2017;95:353-60. https://doi.org/ 10.2527/JAS.2016.0958

69. Bergsma R, Kanis E, Verstegen MWA, van der Peet-Schwering CMC, Knol EF. Lactation efficiency as a result of body composition dynamics and feed intake in sows. Livest Sci. 2009;125:208-22. https://doi.org/10.1016/j.livsci.2009.04.011

70. Thaker MYC, Bilkei G. Lactation weight loss influences subsequent reproductive performance of sows. Anim Reprod Sci. 2005;88:309-18. https://doi.org/10.1016/j.anireprosci.2004.10.001

71. Kemp B, Da Silva CLA, Soede NM. Recent advances in pig reproduction: focus on impact of genetic selection for female fertility. Reprod Domest Anim. 2018;53:28-36. https://doi. org/10.1111/rda.13264

72. Quesnel H, Prunier A. Effect of insulin administration before weaning on reproductive performance in feed-restricted primiparous sows. Anim Reprod Sci. 1998;51:119-29. https://doi. org/10.1016/s0378-4320(98)00061-x

73. Soede NM, Langendijk P, Kemp B. Reproductive cycles in pigs. Anim Reprod Sci. 2011;124:251-8. https://doi.org/10.1016/j.anireprosci.2011.02.025

74. van den Brand H, Dieleman SJ, Soede NM, Kemp B. Dietary energy source at two feeding levels during lactation of primiparous sows: I. effects on glucose, insulin, and luteinizing hormone and on follicle development, weaning-to-estrus interval, and ovulation rate.J Anim Sci. 2000;78:396-404. https://doi.org/10.2527/2000.782396x

75. Guthrie HD, Bolt DJ, Cooper BS. Effects of gonadotropin treatment on ovarian follicle growth and granulosal cell aromatase activity in prepuberal gilts. J Anim Sci. 1990;68:371926. https://doi.org/10.2527/1990.68113719x

76. Soede N, Hazeleger W, Kemp B. Follicle size and the process of ovulation in sows as studied with ultrasound. Reprod Domest Anim. 1998;33:239-44. https://doi.org/10.1111/j.14390531.1998.tb01350.x

77. Yun J, Björkman S, Oliviero C, Soede N, Peltoniemi O. The effect of farrowing duration and parity on preovulatory follicular size and oxytocin release of sows at subsequent oestrus. Re- 
prod Domest Anim. 2018;53:776-83. https://doi.org/10.1111/rda.13170

78. Soede NM, Helmond FA, Kemp B. Periovulatory profiles of oestradiol, LH and progesterone in relation to oestrus and embryo mortality in multiparous sows using transrectal ultrasonography to detect ovulation. J Reprod Fertil. 1994;101:633-41. https://doi.org/10.1530/ jrf.0.1010633

79. Langendijk P, van den Brand H, Soede NM, Kemp B. Effect of boar contact on follicular development and on estrus expression after weaning in primiparous sows. Theriogenology. 2000;54:1295-303. https://doi.org/10.1016/s0093-691x(00)00436-2

80. Langendijk P, Dieleman SJ, van den Ham CM, Hazeleger W, Soede NM, Kemp B. LH pulsatile release patterns, follicular growth and function during repetitive periods of suckling and non-suckling in sows. Theriogenology. 2007;67:1076-86. https://doi.org/10.1016/j.theriogenology.2006.12.008

81. Prunier A, Quesnel H. Influence of the nutritional status on ovarian development in female pigs. Anim Reprod Sci. 2000:60;185-97. https://doi.org/10.1016/s0378-4320(00)00093-2

82. Wientjes J, Soede NM, van den Brand H, Kemp B. Nutritionally induced relationships between insulin levels during the weaning-to-ovulation interval and reproductive characteristics in multiparous sows: II. luteal development, progesterone and conceptus development and uniformity. Reprod Domest Anim. 2012;47:62-8. https://doi.org/10.1111/j.14390531.2011.01802.x

83. Spencer TE, Bazer FW. Biology of progesterone action during pregnancy recognition and maintenance of pregnancy. Front Biosci. 2002;7:d1879-98. https://doi.org/10.2741/spencer

84. Spencer TE, Bazer FW. Uterine and placental factors regulating conceptus growth in domestic animals. J Anim Sci. 2004;82 Suppl 13:E4-13. https://doi.org/10.2527/2004.8213_ supplE4x

85. Hoving LL, Haen SM, Laurenssen BFA, Peltoniemi OAT, Kemp B, Soede NM. Caudal vena cava progesterone and $\mathrm{LH}$ release patterns on Day 14 of gestation in primiparous sows. Reprod Fertil Dev. 2017;29:476-81. https://doi.org/10.1071/RD15016

86. Han T, Björkman S, Soede NM, Oliviero C, Peltoniemi O. Effect of IGF-1 level at weaning on subsequent luteal developement and progesterone production in primiparous sows. Oral session presented at: 11th European Symposium of Porcine Health Management (ESPHM); 2019; Utrecht.

87. Haen SM, Heinonen M, Bjorkman S, Soede NM, Peltoniemi OAT. Progesterone and Luteinizing hormone secretion patterns in early pregnant gilts. Reprod Domest Anim. 2020;55:795-804. https://doi.org/10.1111/rda.13686

88. Haen SM, Heinonen M, Kauffold J, Heikinheimo M, Hoving LL, Soede NM, et al. GnRHagonist deslorelin implant alters the progesterone release pattern during early pregnancy in gilts. Reprod Domest Anim. 2019;54:464-72. https://doi.org/10.1111/rda.13376

89. van der Lende T, Hazeleger W, de Jager D. Weight distribution within litters at the early foetal stage and at birth in relation to embryonic mortality in the pig. Livest Prod Sci. 1990;26:53-65. https://doi.org/10.1016/0301-6226(90)90055-B

90. Singh B, Armstrong DT. Insulin-like growth factor-1, a component of serum that enables porcine cumulus cells to expand in response to follicle-stimulating hormone in vitro. Biol Reprod. 1997;56:1370-5. https://doi.org/10.1095/biolreprod56.6.1370

91. Xia P, Tekpetey FR, Armstrong DT. Effect of IGF-I on pig oocyte maturation, fertilization, and early embryonic development in vitro, and on granulosa and cumulus cell biosynthetic activity. Mol Reprod Dev. 1994;38:373-9. https://doi.org/10.1002/mrd.1080380404

92. Guthrie HD. The follicular phase in pigs: follicle populations, circulating hor- 
mones, follicle factors and oocytes. J Anim Sci. 2005;83 Suppl 13:E79-89. https://doi. org/10.2527/2005.8313_supplE79x

93. Zhou P, Baumgarten SC, Wu Y, Bennett J, Winston N, Hirshfeld-Cytron J, et al. IGF-I signaling is essential for FSH stimulation of AKT and steroidogenic genes in granulosa cells. Mol Endocrinol. 2013;27:511-23. https://doi.org/10.1210/me.2012-1307

94. Wientjes JGM, Soede NM, van den Brand H, Kemp B. Nutritionally induced relationships between insulin levels during the weaning-to-ovulation interval and reproductive characteristics in multiparous sows: I. luteinizing hormone, follicle development, oestrus and ovulation. Reprod Domest Anim. 2012;47:53-61. https://doi.org/10.1111/j.1439-0531.2011.01801.x

95. Langendijk P, van den Brand H, Gerritsen R, Quesnel H, Soede NM, Kemp B. Porcine luteal function in relation to IGF-1 levels following ovulation during lactation or after weaning. Reprod Domest Anim. 2008;43:131-6. https://doi.org/10.1111/j.1439-0531.2007.00865.x

96. Lange-Consiglio A, Perrini C, Albini G, Modina S, Lodde V, Orsini E, et al. Oviductal microvesicles and their effect on in vitro maturation of canine oocytes. Reproduction. 2017;154:167-80. https://doi.org/10.1530/REP-17-0117

97. Da Silva CLA, van den Brand H, Laurenssen BFA, Broekhuijse MLWJ, Knol EF, Kemp $\mathrm{B}$, et al. Relationships between ovulation rate and embryonic and placental characteristics in multiparous sows at 35 days of pregnancy. Animal. 2016;10:1192-9. https://doi.org/10.1017/ S175173111600015X

98. Da Silva CLA, Broekhuijse MLWJ, Laurenssen BFA, Mulder HA, Knol EF, Kemp B, et al. Relationship between ovulation rate and embryonic characteristics in gilts at $35 \mathrm{~d}$ of pregnancy1.J Anim Sci. 2017;95:3160-72. https://doi.org/10.2527/jas.2017.1577

99. Pope WF, Xie S, Broermann DM, Nephew KP. Causes and consequences of early embryonic diversity in pigs. J Reprod Fertil Suppl. 1990;40:251-60.

100. Pope WF. Embryogenesis recapitulates oogenesis in swine. Proc Soc Exp Biol Med. 1992;199:273-81. https://doi.org/10.3181/00379727-199-43356b

101. Geisert RD. Early embryonic survival in the pig: can it be improved? J Anim Sci. 2002;80 Suppl 1:E54-65. https://doi.org/10.2527/animalsci2002.0021881200800ES10009x

102. Waclawik A, Kaczmarek MM, Blitek A, Kaczynski P, Ziecik AJ. Embryo-maternal dialogue during pregnancy establishment and implantation in the pig. Mol Reprod Dev. 2017;84:84255. https://doi.org/10.1002/mrd.22835

103. Xie S, Broermann DM, Nephew KP, Bishop MD, Pope WF. Relationship between oocyte maturation and fertilization on zygotic diversity in swine. J Anim Sci. 1990;68:2027-33. https://doi.org/10.2527/1990.6872027x

104. Stroband HW, van der Lende T. Embryonic and uterine development during early pregnancy in pigs.J Reprod Fertil Suppl. 1990;40:261-77.

105. Ferguson EM, Slevin J, Hunter MG, Edwards SA, Ashworth CJ. Beneficial effects of a high fibre diet on oocyte maturity and embryo survival in gilts. Reproduction. 2007;133:433-9. https://doi.org/10.1530/REP-06-0018

106. van den Brand H, Soede NM, Kemp B. Supplementation of dextrose to the diet during the weaning to estrus interval affects subsequent variation in within-litter piglet birth weight. Anim Reprod Sci. 2006;91:353-8. https://doi.org/10.1016/j.anireprosci.2005.04.009

107. van den Brand H, van Enckevort LCM, Van Der Hoeven EM, Kemp B. Effects of dextrose plus lactose in the sows diet on subsequent reproductive performance and within litter birth weight variation. Reprod Domest Anim. 2009;44:884-8. https://doi.org/10.1111/j.14390531.2008.01106.xs 